\title{
Comprehensive heat treatment using solar energy to produce high quality foam concrete
}

\author{
Batyrkhan Tokmyrza ${ }^{1}$, Lyazat Aruova, ${ }^{2, *}$, Nabi Dauzhanov², Zhumabeke Ospanova ${ }^{2}$, \\ and Aizhan Utkelbaeva ${ }^{3}$ \\ ${ }^{1}$ Nazarbaev_University, Kazakhstan Republic \\ ${ }^{2}$ Eurasian National University named after L.N. Gumilev, Kazakhstan Republic \\ ${ }^{3}$ Kyzylorda state university named after Korkyt Ata, Kazakhstan Republic
}

\begin{abstract}
The article illustrates the possibility of producing products from foam concrete by using effective components and the intensification of solar heating by soft modes, which allows to obtain high-quality material and organize energy-efficient and environmentally friendly production. Solar technology in the production of foam concrete - a new method of heat treatment, which is highly environmentally friendly and safe.
\end{abstract}

\section{Introduction}

With the complex method of solar thermal processing of products from foam concrete, optimum temperature conditions were established during the entire season of operating the helio-poligons. The interrelation between the incoming solar energy in the heated product, the consumption of additional electrical energy and the nature of the formation of the temperature field in concrete depending on its massiveness, i.e. surface area and thickness of products. At the same time, with a decrease in the thickness of the product, in order to obtain the same degree of maturity of concrete at the daily age, it is necessary to overuse a larger amount of additional energy. Therefore, the creation of artificial massifs, with complex solar thermal processing of foam concrete products under the solar grid, helps reduce the consumption of additional electrical energy. Technological measures have been developed to reduce the elongation period of porous foam concrete mass, due to the properties of foaming agents, which, along with the application of the well-known effective method of keeping the concrete mix in a thermos chamber and selecting the optimal waterto-cement (W/C) value. The value of W/C for a specific composition of foam concrete was selected not only in order to accelerate the setting time of the mixture and impart the greatest strength to the material of the foam concrete frame, but also to obtain the most favorable porous structure that ultimately determines the physical and mechanical properties of the material.

\footnotetext{
* Corresponding author: ecoeducation@mail.ru
} 
Foam concrete is one of the most efficient materials for building envelopes. They are characterized by relatively high strength and frost resistance with a relatively low average density. The mass of external walls of foam concrete is 2.5-3.5 times lighter than walls of ceramic brick, and the wall thickness is 1.5-2.5 times smaller than walls of claydite-concrete and silicate brick [1,2].

A significant part of the costs in the production of products and structures of foam concrete accounts for the share of energy carriers used for their heat treatment in order to accelerate hardening $[3,4]$. Therefore, manufacturers of products and structures made of foam concrete are forced to exclude their heat treatment from the technological redistribution. Because of this, the consumption of the binder is significantly increased, the costs associated with the use of high grades of cement and special additives of hardening accelerators, as well as the preparation of large areas for maturing foam concrete products and structures with low turnover of metal forms.

The southern regions of Kazakhstan are characterized by a long hot summer with an outdoor temperature within $35-42^{\circ} \mathrm{C}$, where the level of solar radiation reaches over $6 \mathrm{kWh} / \mathrm{m}^{2}$. Such weather and climatic conditions create reliable prerequisites for the organization of heliopolygons for the production of foam concrete products. Therefore, given the enormous size of regions with favorable weather and climatic conditions, the attraction of solar energy in the production of foam concrete to replace traditional forms of energy has great prospects.

Studies conducted to study the possibility of attracting solar energy in the production of products from foam concrete proved the promise of solar thermal processing for a dry hot climate.

\section{Research methods}

During the development of the full technological cycle of production of foam concrete products, at the site under production conditions developed by solar technology, factory compositions of foam concrete wall products D600-800 were used that meet the requirements of GOST 25485, which used Portland cement M400, quartz sand $\mathrm{M}_{\mathrm{s}}=1.2\left(\mathrm{M}_{\mathrm{s}}-\right.$ size module $)$ and a foaming agent protein.

The foam concrete mixture was made on a foam concrete mixer according to the classical two-stage technology using a foam generator (Figure 1).

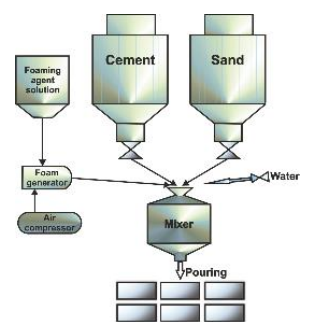

Fig. 1. Diagram of the production technology of foam concrete: 1 - cement and sand bunker; 2 - ready-made foaming solution; 3 - foam generator; 4 - compressor; 5 - foam concrete mixer; 6 - forms.

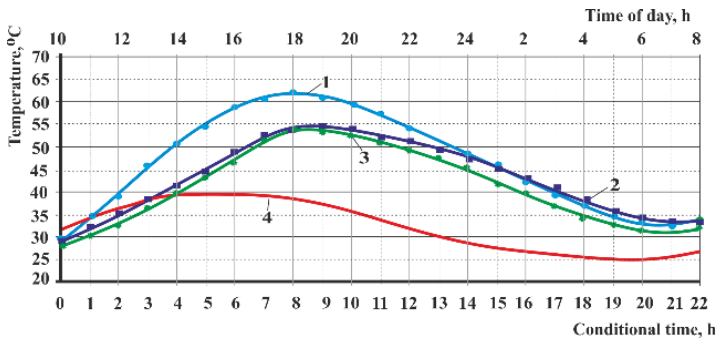

Fig. 2. Heating kinetics of foam concrete products with one-side solar thermal processing. 1 - temperature in the upper zone; 2 - temperature in the middle zone; 3 - temperature in the lower zone of the unit; 4 - air temperature.

After a set of plastic strength of $400-600 \mathrm{~g} / \mathrm{cm}^{2}$, sufficient for solar thermal treatment, the forms with the products are moved to an open landfill for heat treatment using solar energy. To ensure the daily cycle of the turnover of forms and the effective use of solar 
radiation during the day, heating of products in helioforms should be started no later than 10 o'clock in the morning. In this case, the temperature rise in the heliocamera is carried out at a speed of $7-8^{\circ} \mathrm{C} /$ hour for 5-6 hours, and isothermal heating takes 3-4 hours at a temperature of $62-64^{\circ} \mathrm{C}$, then slow cooling takes place in the evening and at night. foam concrete products to a temperature of $33 \pm 2{ }^{\circ} \mathrm{C}$.

\section{Discussion}

The study of the use of solar energy in accelerating the hardening of concrete according to literature data, as well as preliminary studies, allowed to identify the problem with one-side solar thermal processing of foam concrete. It is established that the temperature field throughout the thickness of the array, especially during the first 7-8 hours, is uneven, which significantly affects the heat transfer process that occurs inside the array (Figure 2).

As a result of the resulting gradients of temperature and pressure inside the array, moisture migrates, which in turn slows down the processes of cement hydration. In this case, the greater the thickness of the foam concrete products, the more pronounced the unevenness of the temperature field.

To carry out experiments on solar thermal processing of products of foam concrete with dimensions of $0.2 \times 0.2 \times 0.4 \mathrm{~m}$, helio-covers with a two-layer translucent coating were made. At the same time, the products in the helioform were heated to maximum temperatures in concrete to $62^{\circ} \mathrm{C}$ (upper zones), $55^{\circ} \mathrm{C}$ (middle zones) and $53^{\circ} \mathrm{C}$ (lower zones).

As can be seen, due to the low thermal conductivity of foam concrete, the lower and middle zones of the product warmed up very slowly compared to the upper zone, and since the start of one-sided solar thermal processing for 7 hours, the temperature difference was $10-11^{\circ} \mathrm{C}$, which is not acceptable for subsequent maintenance required qualities and durability of products. The temperature throughout the cross section of the product begins to level off only after 7-8 hours from the beginning of the solar thermal treatment, that is, at night. As the curves in Figure 2 show, the temperature difference over the cross section of the product becomes within the allowable values only after 10 hours from the start of heating. However, it is during the first 6-7 hours in foam concrete with a still unformed structure, because of unacceptable temperature gradients and pressure inside the array, destructive processes occur that have a negative effect on its physical and mechanical properties.

Thus, according to the proposed solar thermal processing technology, solar radiation is delivered to the foam concrete products through a solar cell with a two-layer translucent coating, and additional thermal energy is supplied to the products from the bottom of the metal forms, that is, opposite to the sun-receiving surface. For this purpose, various types of heat heaters are used, which convert electrical energy into heat.

Modes of complex solar thermal processing should ensure the acquisition of products made of foam concrete made on Portland cement at a daily age of 45-55\% strength depending on the brand on the average density of the products, the initial mineralogical composition of the cement used, air temperature, and other technological factors.

\section{The effectiveness of complex solar thermal processing of products from foam concrete, depending on the massiveness of products at low positive temperatures}

According to $[5,6]$, the heating of products due to the use of solar radiation occurs more intensively with a smaller thickness and the greatest sun-receiving surface. Therefore, it is 
of interest to study the effect of the massiveness of the product on the efficiency of the integrated solar thermal treatment with the use of solar covers with minimal solar radiation during the spring and autumn periods of the year. This interest is also due to the fact that in the previous stages of the study, research was conducted mainly on blocks having a thickness of $0.2 \mathrm{~m}$ and on standard cubes with sides of $0.1 \mathrm{~m}$.

For this purpose, experimental studies were conducted on foam concrete with a $\mathrm{W} / \mathrm{C}=0.6$, with a minimum positive air temperature of $+5^{\circ} \mathrm{C}$. The studied samples had the following different sizes: 1) $0.1 \times 0.6 \times 1.8 \mathrm{~m}$; 2) $0.2 \times 0.6 \times 1.2 \mathrm{~m}$; 3 ) $0.3 \times 0.6 \times 0.6 \mathrm{~m}$ and were respectively with different moduli of the open surface, $\mathbf{M}_{\text {o.s. }}\left(\mathbf{M}_{\text {o.s. }}=20 ; 10\right.$; $3.3 \mathrm{~m}^{-1}$ ). Foam concrete arrays, hardening under the solar cover and in an open form, were heated with the help of additional (electrical) energy until the same degrees of maturity were obtained at day old.

As follows from the analysis of the results of experiments Table 1 and Figure 3, the energy consumption $\left(\mathrm{kWh} / \mathrm{m}^{3}\right)$ for heating foam concrete hardening in the form under a solar grid, depending on the thickness of the products $(\delta)$ (and the modulus of the open surface) is as follows: $91-$ at $\delta=0.1 \mathrm{~m}\left(\mathrm{M}_{\text {o.s. }}=20 \mathrm{~m}^{-1}\right) ; 41-$ at $\delta=0.2 \mathrm{~m}\left(\mathrm{M}_{\text {o.s. }}=10 \mathrm{~m}^{-1}\right)$; $37-$ at $\delta=0.3 \mathrm{~m}\left(\mathrm{M}_{\text {o.s. }}=3.3 \mathrm{~m}^{-1}\right)$.

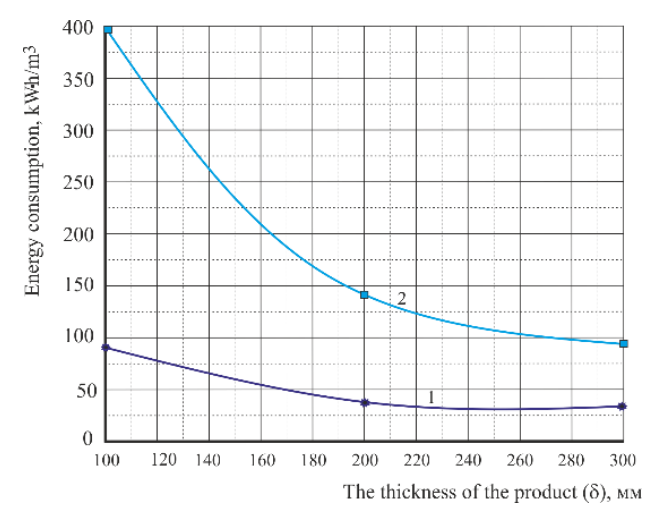

Fig. 3. Dependence of energy consumption on the thickness of foam concrete products during heating by the averaged mode (air temperature + $\left.5^{\circ} \mathrm{C}\right) 1$ - under the solar grid; 2 - in the open form.

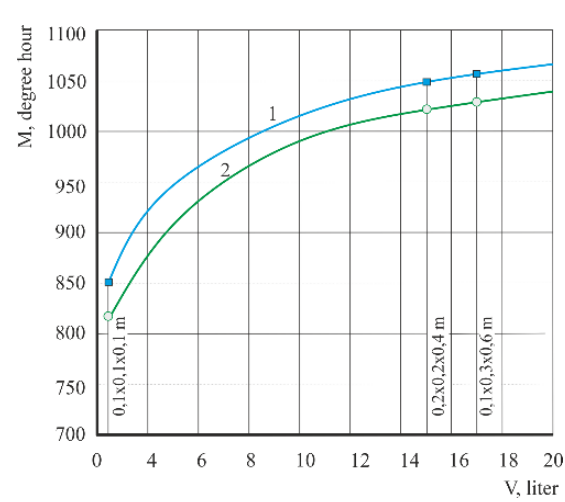

Fig. 4. The effect of sample sizes on their heat content when hardening under the solar cover. 1 - in the upper zone ( $5 \mathrm{~mm}$ from the surface); 2 -in the center of the samples.

The amount of energy saved $\left(\mathrm{kWh} / \mathrm{m}^{3}\right)$ in solar thermal treatment of foam concrete with a solar cover installed on the shape, compared with a similar product, but in the form of an open surface (i.e. without a solar cap), depending on the thickness of the products $(\delta)$ $306-$ at $\delta=0.1 \mathrm{~m} ; 99-$ at $\delta=0.2 \mathrm{~m}$; and $60-$ at $\delta=0.3 \mathrm{~m}$.

Thus, in order to obtain the same degree of maturity of foam concrete at the daily age, the amount of additional energy required increases with decreasing product thickness.

This is explained by the fact that, firstly, a large open surface leads to large heat losses, secondly, as the thickness of the products decreases, their heat storage capacity decreases, and thirdly, the specific heat release of cement per surface unit decreases.

The results of experimental studies and data analysis allow us to conclude that the efficiency of complex solar thermal treatment using solar roofs at low positive temperatures (characteristic of early spring and late autumn) from the standpoint of saving the additional electrical energy used, along with solar energy, is thicker heated products. 
Table 1. Effect of thickness of the products on the consumption of electrical (additional) energy used to heat the foam concrete in the helioform at an air temperature of $+5^{\circ} \mathrm{C}$.

\begin{tabular}{|c|c|c|c|c|c|c|c|c|c|c|}
\hline \multirow{4}{*}{$\begin{array}{l}\text { Produc } \\
\mathrm{t} \\
\text { thickn } \\
\text { ess, } m\end{array}$} & \multicolumn{10}{|c|}{ Hardening conditions of foam concrete blocks } \\
\hline & \multicolumn{5}{|c|}{ Under the solar cap } & \multicolumn{5}{|c|}{ In open form } \\
\hline & \multicolumn{4}{|c|}{$\begin{array}{c}\text { The degree of matureness } \\
\text { (degrees/h) foam concrete after } \\
22 \text { hours. }\end{array}$} & \multirow{2}{*}{$\begin{array}{c}\text { Energy } \\
\text { consumpt } \\
\text { ion, } \mathrm{kWh} \\
/ \mathrm{m}^{3}\end{array}$} & \multicolumn{4}{|c|}{$\begin{array}{c}\text { The degree of matureness } \\
\text { (degrees/h) foam concrete after } \\
22 \text { hours. }\end{array}$} & \multirow{2}{*}{$\begin{array}{c}\text { Energy } \\
\text { consump } \\
\text { ion, } \\
\mathrm{kWh} / \mathrm{m}^{3}\end{array}$} \\
\hline & $\begin{array}{l}\text { lower } \\
\text { area } \\
\text { of } \\
\text { produ } \\
\text { cts }\end{array}$ & $\begin{array}{c}\text { centr } \\
\text { al } \\
\text { prod } \\
\text { uct } \\
\text { area }\end{array}$ & $\begin{array}{c}\text { uppe } \\
\text { r } \\
\text { prod } \\
\text { uct } \\
\text { area }\end{array}$ & $\begin{array}{c}\text { avera } \\
\text { ge } \\
\text { value }\end{array}$ & & $\begin{array}{l}\text { lower } \\
\text { area } \\
\text { of } \\
\text { produ } \\
\text { cts }\end{array}$ & $\begin{array}{c}\text { centr } \\
\text { al } \\
\text { prod } \\
\text { uct } \\
\text { area }\end{array}$ & $\begin{array}{c}\text { uppe } \\
\text { r } \\
\text { prod } \\
\text { uct } \\
\text { area }\end{array}$ & $\begin{array}{c}\text { avera } \\
\text { ge } \\
\text { value }\end{array}$ & \\
\hline 0.10 & 993 & 961 & 935 & 963 & 91 & 1077 & 973 & 822 & 957 & 397 \\
\hline 0.20 & 1136 & 1016 & 920 & 1024 & 41 & 1413 & 1013 & 601 & 1009 & 140 \\
\hline 0.30 & 1321 & 999 & 807 & 1042 & 37 & 1719 & 998 & 338 & 1018 & 97 \\
\hline
\end{tabular}

The influence of the size of foam concrete samples on their heat content during hardening under the solar cover. It was established that a large role in the heating of foam concrete, and as a result - the increase in its strength, plays a large-scale factor. Therefore, in some cases, in order to approach real products, besides standard cube samples with side sizes of $10 \times 10 \times 10 \mathrm{~cm}$, blocks of $20 \times 20 \times 40 \mathrm{~cm}$ and $10 \times 30 \times 60 \mathrm{~cm}$ were used, which allow the simulation of thermal conditions in products (Figure 4).

The study of the kinetics of heating of real products, the curing of foam concrete when hardening under a solar cap, and the development of optimal technological parameters for the production of products of various sizes were made in August on the basis of a workshop for the production of foam concrete products in Kyzylorda (Republic of Kazakhstan), testing the developed solar technology.

In studies conducted under production conditions, factory formulations of foam concrete wall products D700 (B2) were used, meeting the requirements of GOST 25485, in which cement from the Dzhambulsky plant (PC400-D20), sand quartz $\mathrm{M}_{\mathrm{s}}=1.2$ and a foaming agent were used.

When studying the kinetics of heating products, depending on their thickness and massiveness, thermal sensors were installed at a height in one characteristic point of foam concrete arrays. Based on the experimental data, their heating in the forms under the solar cap is carried out in mild regimes. During the first hours of the start of heat treatment, the heating rate of the array is no more than $7^{\circ} \mathrm{C} / \mathrm{h}$, after $6-7$ hours the heating rate increases, and isothermal aging is carried out at a temperature of $60-64^{\circ} \mathrm{C}$, for $3-4$ hours. Cooling of products occurs at a slow rate of $4-6^{\circ} \mathrm{C} / \mathrm{h}$ to a temperature of $31-39^{\circ} \mathrm{C}$, from evening to morning.

At the same time, products having a smaller thickness and with the largest open, sunreceiving surface are heated up faster. Thus, a product with $\delta=0.1 \mathrm{~m}$ reached a maximum temperature of $64^{\circ} \mathrm{C}$ in 7 hours, a product with $=0.2 \mathrm{~m}$, at $-63^{\circ} \mathrm{C}$ in 9 hours, and a product with $\delta=0.3 \mathrm{~m}$, at $-63^{\circ} \mathrm{C}$ in 10 hours.

The process of cooling products in the non-solar time of day with a decrease in their thickness, also occurs more intensively. Therefore, in the foam concrete heap with $\mathrm{c}=0.1 \mathrm{~m}$, the cooling start time is faster, and its speed is higher. The total number of degree hours obtained by hardening foam concrete is $1061,1071,1119$, respectively, and the values of extreme temperature gradients are $0.25-0.5^{\circ} \mathrm{C} / \mathrm{cm}$. At the same time, the number of degree hours, obtained by a standard sample hardened under an individual solar cap, is only 812 .

The nature of the heating and cooling of concrete in a standard cube sample with an edge of $0.1 \mathrm{~m}$, as well as the degree of maturity of foam concrete, indicates a discrepancy 
between the temperature field in the sample and products. As a result, special methods for controlling the strength of concrete should be provided.

Thus, due to the influence of the heating foam concrete mass and cement exotherm, the temperature regimes of the products cannot be modeled on standard control samples of concrete. It was revealed that the degree of maturity of concrete in an array with a thickness of $0.1-0.3 \mathrm{~m}$, respectively, is $25-40 \%$ higher than in standard samples, which indicates errors in the control of the strength of concrete products on heliopoligons using standard samples that were hard under a solar cover stand

\section{Measures to solve the problems of prolonged setting and hardening of foam concrete}

The causes of prolonged periods of setting and low speed of hardening of foam concrete, associated with the specific properties of foaming agents, have been studied in well-known studies on the process of hydration of Portland cement in cellular concrete. As the analysis of research aimed at finding solutions to this problem shows, an effective method of accelerating the setting and hardening is a technological method for creating optimal conditions - using thermos chambers with a temperature of $3-5^{\circ} \mathrm{C}$ higher than the initial temperature of the porous mixture [7,8].

When choosing a W/C, it should be noted that the strength of the foam concrete as a whole is no less affected by the geometry of the porosity of the framework, rather than the strength of the framework material itself. Therefore, the optimal value of W/C is selected not only from the point of view of imparting the greatest strength to the material of the foam concrete frame, but also to obtain the most favorable porous structure. To do this, the initial mixture must have a W/C in which its fluidity will not impede the formation of an optimal porous structure. The negative side of the increase in the W/C is a later setting time for the binder and a decrease in the strength characteristics of the foam concrete. W/C variation should be viewed as a search for a compromise between density and strength. With the most successful combination of both and other influences of the W/C factor, its value will be optimal for the given case (Figure 5).

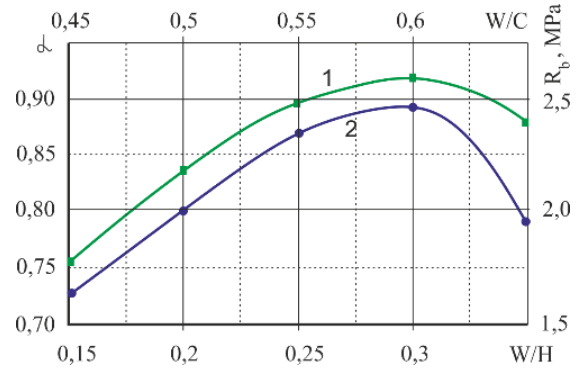

Fig. 5. A graph of the strength of foam concrete in compression (curve-1) and the utilization rate of the foaming agent (curve-2) on the amount of water in the mixture.

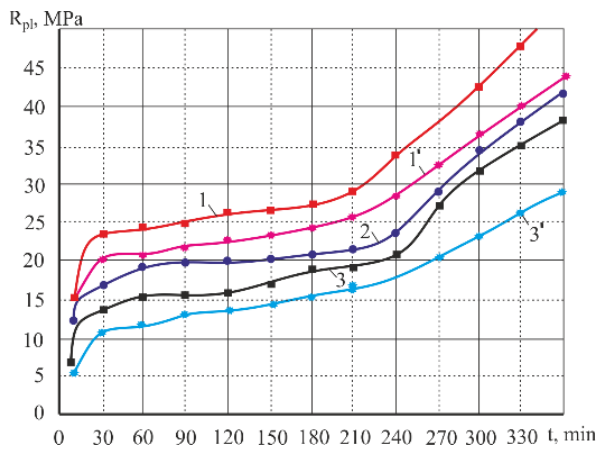

Fig. 6. Graph of the effect of $\mathrm{W} / \mathrm{C}$ on the kinetics of plastic strength. W/C: $1-0.5 ; 2-0.6 ; 3-0.7$; 1 ' $-0.5 ; 3$ ' -0.7 .

As a result of the analysis of known studies on the hydration of cement paste in a foam concrete mixture, it was found that due to the fact that water contained in foam films, as well as in the pores of the gel and sorbed water do not participate in hydration, the process most fully occurs at high W/C $[9,10]$. 
In order to study the kinetics of plastic strength of a porous mixture depending on the $\mathrm{W} / \mathrm{C}$ and the type of foaming agent, experimental studies were carried out using the above-stated factory compositions of foam concrete, the results of which are shown in Figure 5.

An analysis of the results obtained, as well as a generalization of the well-known works [11], devoted to the intensification of the plastic strength of the foam concrete mixture shows that the mobility of the cement paste may also depend on the nature of the foam-former. At the same time, the spread ability of the cement paste when mixing it with a solution of synthetic surfactant is obtained more than in the case of using protein surfactant.

On the protein foam-former, (Figure 6, curves 1,2,3) with increasing $\mathrm{W} / \mathrm{C}$, the plastic strength of the concrete mix decreases, and the period of structure formation is lengthened. With similar values of W/C, if a synthetic foaming agent is used (curves 1', 3'), the rate of plastic strength of the mixture becomes even slower and its values are significantly lower than when using protein foam-former. For the studied compositions of foam concrete with a given density of $700 \mathrm{~kg} / \mathrm{m}^{3}$ (curve 2), the optimal value of $\mathrm{W} / \mathrm{C}=0.6$ was established on the protein foaming agent, which provides an intensive increase in plastic strength and an optimal porous structure of the material.

The obtained results show the possibility of influencing the kinetics of plastic strength of foam concrete through the W/C mixture, as well as to increase the stability of foam-cement mixtures in the production of foam concrete without the use of stabilizers, it is advisable to use protein foam-former that have high structural and mechanical characteristics and low adsorption on cement particles.

Analysis of the known solutions to accelerate the hardening of foam concrete suggests that the use of plasticizers, which reduce the water-cement ratio of the concrete mix, can give a tangible effect of accelerated product strength.

Therefore, it is of interest to study the effect of the C-3 superplasticizer on the hardening intensity and strength of the complex solar thermal processing foam concrete products subjected to a protein foaming agent. For experimental studies, compounds similar to previous experiments were used - D700, B2. For the optimality criterion were adopted the fluidity of the concrete mix, the reduction of $\mathrm{W} / \mathrm{C}$, as well as the daily strength of the products. On the basis of the results obtained, the optimal dosage of C-3 superplasticizer was established, which was $0.7 \%$ of the binder mass, for products hardening at temperatures from $18-20^{\circ} \mathrm{C}$ to $60-65^{\circ} \mathrm{C}$, which somewhat compensates for the negative effect of temperature.

It has been established that the introduction of C-3 superplasticizer into foam concrete allows, at a constant mobility of the mixture, to reduce the amount of mixing water by $12-18 \%$ and to intensify the initial hardening of the concrete. However, the effect of the introduction of a superplasticizer increases with a decrease in the hardening temperature and $\mathrm{W} / \mathrm{C}$ of the concrete, while the optimum temperature of the hardening concrete for applying C-3 is $-35-40^{\circ} \mathrm{C}$.

In addition to the above methods of accelerating the setting time and hardening of foam concrete, another technological method is known to increase the intensity of hardening of foam concrete, for solar thermal processing of products - the rational use of the internal heat source.

\section{Conclusion}

The research results obtained under production conditions proved their complete convergence with the results of experiments obtained under laboratory conditions, which 
confirms the high efficiency of the developed method of integrated solar thermal processing of products using solar and additional electric energy.

It has been established that the values of limiting temperature gradients mainly depend on the formation of the pore structure of foam concrete by the time of the start of heating and can reach $0.3-0.7^{\circ} \mathrm{C} / \mathrm{cm}$.

The interrelation between the incoming solar energy in the heated product, the consumption of additional electrical energy and the nature of the formation of the temperature field in concrete depending on its massiveness, i.e. surface area and thickness of products.

Technological measures have been developed to reduce the elongation period of porous foam concrete mass, due to the properties of foaming agents, which, along with the application of the well-known effective method of keeping the concrete mix in a thermos chamber and selecting the optimal W/C value.

The initial data necessary for the design of lines for the production of products from foam concrete at landfills according to the developed method of solar thermal processing have been established.

The possibility of producing products from foam concrete due to the use of effective components and the intensification of hardening by solar heating under soft conditions, which allows to obtain high-quality material and organize energy-efficient and environmentally friendly production, is shown. Solar technology in the production of foam concrete - a new method of heat treatment, which is highly environmentally friendly and safe.

\section{References}

1. B. A. Pinsker, State and problems of production and use of cellular concrete (The international scientific-practical conference, 21-23 April 2004 "Interregional North-Western Construction Chamber", 2004)

2. E. Namsone, G. Šahmenko, A. Korjakins, Procedia Engineering 172, 760-767 (2017)

3. K. Ramamurthy, M. E. Kumar, Construction and Building Materials 95, 25 (2015)

4. B. V Gusev, T. V. Kuznetsova, Cement and concrete - development trends (The scientific world, 2012)

5. B. V. Gusev, V. R. Falikman, Structural Concrete in The Age Of Sustainable Development 305, 36.1-36.12 (2015)

6. L. B. Aruova, N. T. Dauzhanov, International Journal of Engineering \& Technology 7, 4.1, 36-41 (2018)

7. N. I. Podgornov, Heat treatment of concrete using solar energy (Moscow Publishing House ABC, 2010)

8. L. B. Aruova, N. T. Dauzhanov, MOJ Civil Engineering 3, 3, 1-7 (2017)

9. E. P. Kearsley, P. J. Wainwright, Cement and Concrete Research 32, 241-246 (2002)

10. Y. H. Mugahed Amran, R. S. M. Rashid, F. Hejazi, A. A. Abang Ali, N. A. Safiee, S. M. Bida, KSCE Journal of Civil Engineering 22, 4, 1179-1192 (2018)

11. L. Aruova, N. Dauzhanov, Mediterranean Journal of Social Sciences 5, 23 (2014) 